\title{
Patterns of reinnervation and blood flow in split-skin grafts
}

\author{
A Juma FRCS(Plast $)^{1}$, D Oudit MRCSEd ${ }^{2}$, M Ellabban MD MSc FRCS ${ }^{3}$
}

\begin{abstract}
A Juma, D Oudit, M Ellabban. Patterns of reinnervation and blood flow in split-skin grafts. Can J Plast Surg 2005;13(3):133-137.
\end{abstract}

One of the most important functions of skin is thermoregulation. The alterations in the patterns of blood flow in skin is one of the main physiological processes responsible for thermoregulatory control. The mechanisms governing the thermoregulatory control of cutaneous blood flow are mainly neural and chemical in nature. At present, there is a lack of studies in the literature looking at the relationship between reinnervation and the blood flow pattern of skin grafts.

The present study uses Laser Doppler flowmetry and the immunohistochemical stains protein gene product 9.5, calcitonin gene-related peptide and substance $\mathrm{P}$ to identify nerve fibres, and antibodies to CD31 and von Willebrand factor to identify endothelial tissues. The aim of the present study was to investigate the patterns of blood flow and nerve tissue regeneration in split-skin grafts up to 15 years following the original procedure. Thirty-two split-skin grafts were studied and these were placed into two groups based on the nature of the bed of excision: group I consisted of patients who underwent tangential excision and split-skin grafting $(n=17)$, and group II consisted of patients with split-skin grafts placed onto fascial beds $(n=15)$. Each subpopulation of patients was further divided into three groups based on the length of time following grafting: one to three years, four to six years and seven to 15 years. These divisions were arbitrarily chosen and called A1, A2 and A3, respectively. In the Laser Doppler flowmetry arm of the study, the grafts were assessed at various stages after heating, cooling and further reheating.

The Laser Doppler flowmetry studies showed that, on subjecting the skin grafts in both groups I and II to heating and cooling followed by reheating, the overall response of the blood flow to changes in the temperature was slower.

The immunohistochemical analysis showed that in all graft types and graft ages, protein gene product 9.5, calcitonin gene-related peptide and substance $P$ stains demonstrated a relative lack of the presence of nerve fibres in the split-skin grafts compared with the control ('normal' skin). However, von Willebrand factor and CD31 immunological staining demonstrated that vessels were present in the split-skin grafts, with no significant difference in size or quantity from the control samples.

It was found that the blood flow in the split-skin graft in response to thermal challenge, although present, was slower than that of normal skin, a finding which was independent of the age of the skin graft. It is thought that this was related to a lack of regeneration of nerve fibres and, hence, a deficiency in the neurally mediated reflexes of the blood vessels within the split-skin grafts.

\section{Modes de réinnervation et circulation san- guine dans les greffes de demi-épaisseur}

L'une des plus importantes fonctions de la peau est la thermorégulation. Les altérations de la circulation sanguine dans la peau demeurent parm les principaux processus physiologiques à l'origine de la thermorégulation. Les mécanismes qui régissent la thermorégulation de la circulation sanguine cutanée sont principalement de nature neurale et chimique. Encore trop peu d'études ont été faites et publiées à propos du lien entre la réinnervation et la circulation sanguine dans les greffes cutanées. La présente étude repose sur l'utilisation de la débitmétrie Doppler à laser et sur des colorations immunohistochimiques avec le produit du gène de protéine 9.5 , le peptide lié au gène de la calcitonine et la substance $\mathrm{P}$ dans le but d'identifier les fibres nerveuses et les anticorps dirigés contre le CD31 et contre le facteur de von Willebrand pour visualiser les tissus endothéliaux. Le but de la présente étude était d'explorer les modes de régénération de la circulation sanguine et des tissus nerveux dans des greffes de demiépaisseur, jusqu'à 15 ans après l'intervention originale. Trente-deux greffes de demi-épaisseur ont été étudiées et elles ont été classées en deux groupes selon la nature du lit d'excision : groupe I, composé de patients ayant subi une excision tangentielle et une greffe de demi-épaisseur $(n=17)$ et groupe II, comportant des patients ayant subi des greffes de demi-épaisseur de fascias $(\mathrm{n}=15)$. Chaque sous-groupe de patients a été de nouveau divisé en trois groupes selon la durée des greffons : 1 à 3 ans, 4 à 6 ans et 7 à 15 ans. Ces subdivisions ont été choisies arbitrairement et nommées $\mathrm{A} 1, \mathrm{~A} 2$ et $\mathrm{A} 3$, respectivement. Dans le groupe de l'étude soumis à la débitmétrie Doppler à laser, les greffons ont été évalués à divers stades après application de chaleur, de froid et de chaleur à nouveau.

Les analyses de débitmétrie Doppler à laser ont montré qu'en soumettant les greffons cutanés des groupes I et II à la chaleur puis au froid, suivi de chaleur à nouveau, la réponse globale de la circulation sanguine aux changements de température était plus lente.

L'analyse immunohistochimique a montré que dans tous les types de greffe, la coloration par produit du gène de protéine 9.5 , peptide lié au gène de la calcitonine et substance $\mathrm{P}$ a révélé une absence relative de fibres nerveuses dans les greffes de demi-épaisseur comparativement aux témoins (peau «normale »). Par contre, la coloration immunologique du facteur de von Willebrand et du CD31 a montré que les vaisseaux étaient absents des greffes de demi-épaisseur sans différence significative de taille ou de quantité comparativement aux échantillons témoins.

On a découvert que la circulation sanguine dans le greffon de demiépaisseur en réponse aux changements de température, bien que présente, est plus lente que dans la peau normale, un phénomène qui serait indépendant de l'âge du greffon et que l'on croit relié à l'absence de régénération des fibres nerveuses et donc à un déficit des réflexes neuraux des vaisseaux sanguins dans les greffons de demi-épaisseur.

Key Words: Blood flow; Laser Doppler flowmetry; Reinnervation; Split-skin graft

${ }^{1}$ Countess of Chester Foundation Hospital, Chester; ${ }^{2}$ South Manchester University Hospitals, Manchester, United Kingdom; ${ }^{3}$ Aberdeen Royal Infirmary, Aberdeen, Scotland

Correspondence: Mr Ali Juma, Countess of Chester Hospital NHS Foundation Trust, Countess of Chester Health Park, Liverpool Road, Chester, Cheshire Ch2 1Ul, United Kingdom. Telephone 011-44-785-546-6345, e-mail alijumas@aol.com 
$\mathrm{O}$ ne of the most important functions of skin is thermoregulation. Alterations in the pattern of blood flow in skin are important for thermoregulatory control. The mechanisms governing the thermoregulatory control of cutaneous blood flow are mainly neural and chemical in nature (1).

Studies (2) have indicated that there is a close relationship between nerve fibres and blood vessels during regeneration in skin flaps. Others have stated that an adequate circulation in flaps at operation is essential for sensory reinnervation (3). However, there has been a lack of studies in the literature looking at the relationship between sensory reinnervation and revascularization in split-skin grafts.

The present study uses Laser Doppler flowmetry and immunological stains to study the patterns of blood flow and nerve tissue regeneration in split-skin grafts up to 15 years following the original procedure.

\section{METHODS}

Thirty-two patients who had skin grafts to the lower limbs were included in the present study following local Ethics Committee approval. These patients were divided into two groups depending on the nature of the excision bed. These included:

1. thermally injured patients with partial thickness burns which were treated with tangential excision and split-skin grafting, ie, excision of epidermis and a variable thickness of dermis (group I) $(\mathrm{n}=17)$; and

2. patients who underwent wider excision of malignant melanoma down to deep fascia and split-skin grafting (group II) $(\mathrm{n}=15)$.

Each subpopulation of patients was further subdivided into three groups based on the length of time following grafting: one to three years, four to six years and seven to 15 years. These divisions were arbitrarily chosen and called A1, A2 and A3, respectively.

The study was carried out in a room with controlled environmental parameters. Patients first had their baseline skin graft and body temperatures (T1) measured using a digital thermometer. The baseline blood flow was measured at room temperature using a pulse diode Laser Doppler probe supplied by Perimed (Sweden).

The skin temperature was increased, using a thermode in direct contact with the skin, to $42^{\circ} \mathrm{C}$ and the blood flow was recorded then (T2) and at $1 \mathrm{~min}$ (T3) and $3 \mathrm{~min}$ (T4) from the initial increase in temperature. The skin was then allowed to cool and the blood flow was noted after $1 \mathrm{~min}, 5 \mathrm{~min}$ and $10 \mathrm{~min}(\mathrm{O} 1, \mathrm{O} 2$ and $\mathrm{O} 3$, respectively). The skin was then reheated to $42^{\circ} \mathrm{C}$ and the skin blood flow was noted at $1 \mathrm{~min}$ and $3 \mathrm{~min}$ (R2 and R3, respectively).

At a later date, six of the 32 patients agreed to undergo skin biopsies under local anaesthetic. A $1.0 \mathrm{~cm} \times 0.5 \mathrm{~cm}$ ellipse of skin was excised from both 'normal' skin (control) and the skin grafts. These samples were subjected to immunohistochemical analysis using the following stains: protein gene product 9.5 (PGP 9.5), calcitonin gene-related peptide (CGRP), substance P (SubP), von Willebrand factor (vWf) and CD31 monoclonal antibodies.

PGP 9.5 is a panneural marker (4) and was immune-labelled to demonstrate the pattern and degree of reinnervation. CGRP is found in the dermal papillae and free epidermal nerve endings (5). Vasointestinal polypeptide immune-reactive nerve fibres are present around the arterial segments and the deep and superficial vascular plexuses (6). SubP is found in the nerve fibres of skin that localizes around the blood vessels in the dermis of the skin (7). vWf is a marker for vascular endothelial cells. CD31 is a glycoprotein expressed by vascular endothelial cells and is involved in platelet adhesion in inflammation and in wound healing (8). The use of vWf polyclonal antibodies was supplemented in selected cases using the CD31 monoclonal antibody to demonstrate endothelial cells at different stages of maturity.

The immunofluorescence was captured on an optical disc using a computerized charge-coupled device camera. The fluorescent image was subjected to analysis using a Seescan image analyzer (Seescan, United Kingdom). The data for each image included the percentage of red on the visual display unit screen and the intensity as measured by the fluorescence in the frame of highpower magnification on the screen. In the case of $\mathrm{vWf}$ and CD31, the feret diameter, which is a measure of the internal diameter of the vessels, was also noted.

Following advice from a statistician, the data collected for the immune analysis were summated and subjected to paired $t$ table and univariate analysis. The data collected for the Laser Doppler flowmetry arm of the study were analyzed using paired $t$ tables and univariate analysis for group I and group II.

\section{RESULTS}

For the Laser Doppler flowmetry test, there was no statistically significant difference in the mean baseline blood flow in group I for all the grafts (A1 to A3) between the test and control areas. This overall pattern was also noted on the skin grafts in group II, apart from the skin grafts in the A3 group, where there was a statistically significant difference between the test and control $(\mathrm{P} \leq 0.01)$.

In the heating section of the study (T2, T3 and T4), the heating curve for group I was significantly different for the more 'mature' grafts (A2 and A3) and the ultimate mean blood flow at $\mathrm{T} 4$ was higher for the control at $\mathrm{P} \leq 0.03$. In group II, the pattern of behaviour was somewhat similar to group I but was significant at $\mathrm{P} \leq 0.05$.

In the cooling section ( $\mathrm{T} 4$ to $\mathrm{O} 2$ and $\mathrm{O} 3$ ), in group I, the final mean cooling blood flow (O3 mean velocity [vm]) was not significantly different from $\mathrm{A} 1$ to $\mathrm{A} 3$ at $\mathrm{P} \geq 0.06$. Skin grafts were noted to achieve a lower velocity at $1^{\circ} \mathrm{C}$ higher than the 'normal' skin. In group II, the A1 and A2 samples were too small to analyze, but the A3 sample showed a significant difference $(\mathrm{P} \leq 0.02)$ between the means of the control and test.

When reheated (O4 to $\mathrm{R} 2$ and $\mathrm{R} 3 \mathrm{vm}$ ), there was a significant difference $(\mathrm{P} \leq 0.05)$ in the reheating curve and $\mathrm{O} 3 \mathrm{vm}$ for the grafts in group I and group II (for all graft ages, apart from those in the A3 group in group I) (Figures 1, 2 and 3).

Skin biopsies were performed on six patients who had skin grafts and the data were analyzed using paired $t$ tests. The Seescan analysis showed that in all graft types and ages, the panneural stain (PGP 9.5) showed a significant difference $(\mathrm{P}=0.025)$ for the percentage of red in frame, which reflected the amount of stain uptake. For CGRP, the difference was noted at $\mathrm{P} \leq 0.001$ for both percentage of red in frame and intensity. This finding was also similar to those for SubP $(\mathrm{P} \leq 0.006)$ (Table 1).

The results for CD31 and vWf staining showed that there was no significant difference $(P \geq 0.10)$ between the means of the test and control population for percentage of red in the frame and intensity (Figure 4, Table 2). This was also found to be the case with the feret diameter, a measurement reflecting the average internal diameter of the vessels in the samples analyzed (Figure 5). 


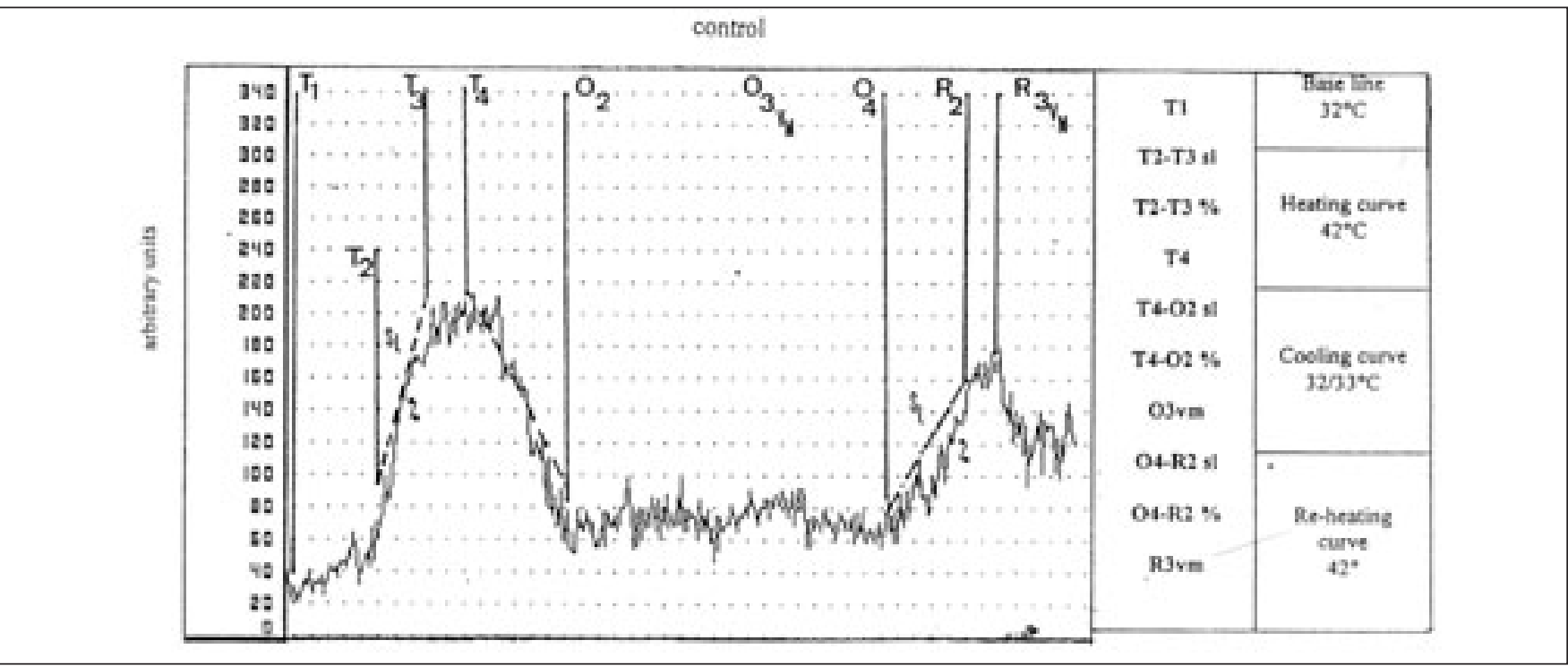

Figure 1) Graphical representation of the results of the Laser Doppler flowmetry to demonstrate the measurements made at the designated time intervals. O3vm Mean velocity at the end of cooling; O4-R2 sl Reheating curve gradient; R3vm Reheating curve mean blood flow at $42^{\circ} \mathrm{C}$; $\mathrm{T} 1 \mathrm{Baseline}$ skin blood flow; T2-T3 sl Heating curve gradient; T4 Maximum blood flow at 42 ${ }^{\circ} \mathrm{C}$; T4-O2 sl Cooling curve gradient

\section{Perfusion in arbitrary units}
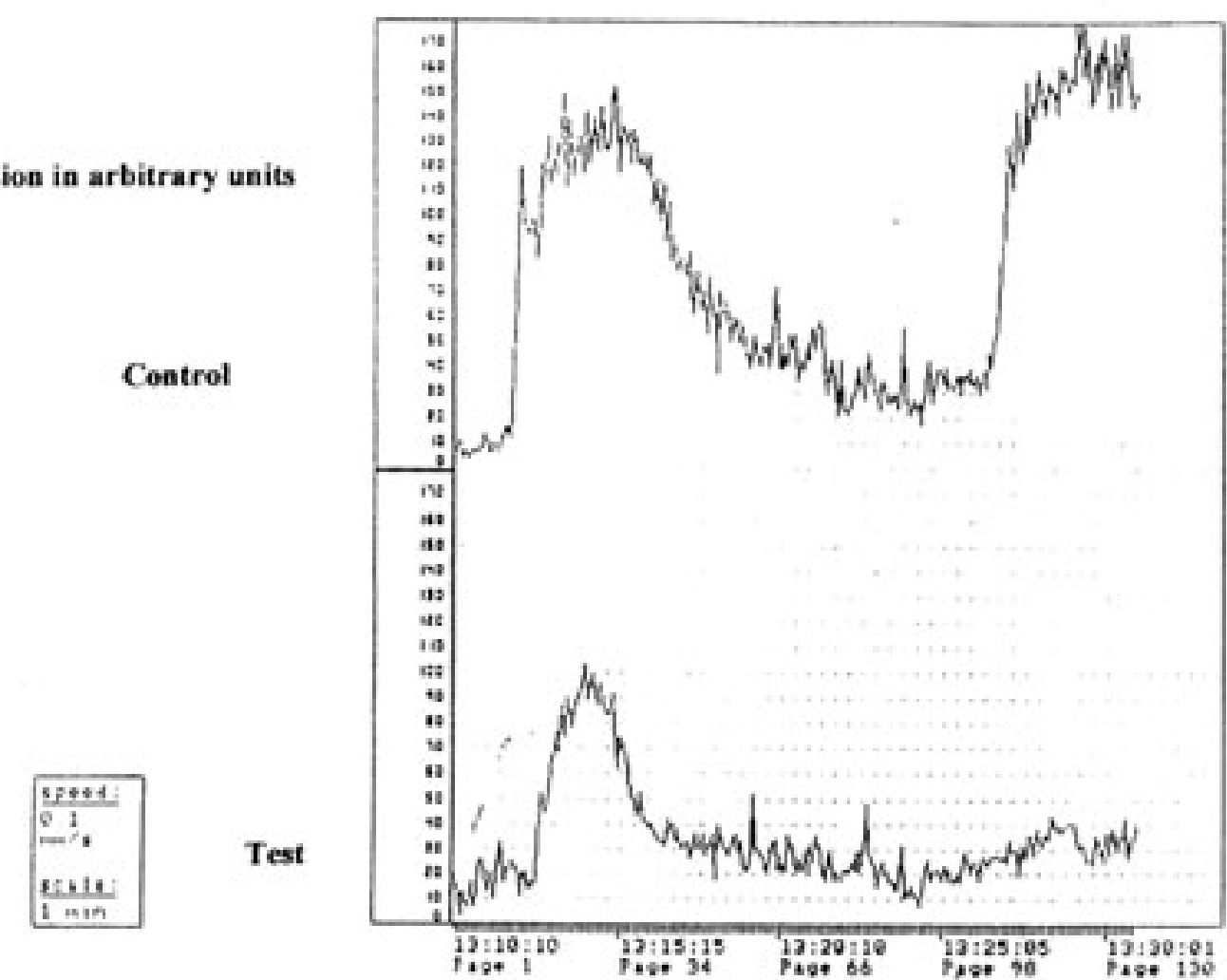

Figure 2) Graphical representation of the results of the Laser Doppler measurements for group I

\section{DISCUSSION}

One of the main functions of skin is to maintain thermoregulatory homeostasis. Thermoregulatory control is the main determinant of blood flow in the microcirculatory systems of the skin. The mechanisms governing the thermoregulatory control of cutaneous blood flow are mainly neural and chemical in nature (1).
Terenghi (2), based on studies on flaps, reported that there is a close relationship between nerve fibres and blood vessels during reinnervation and that angiogenesis precedes the reinnervation of flaps. However, there is a lack of studies in the literature looking at the relationship among reinnervation, neovascularization and blood flow in the microcirculation of split-skin grafts. 


\section{Perfusion in arbitrary units}
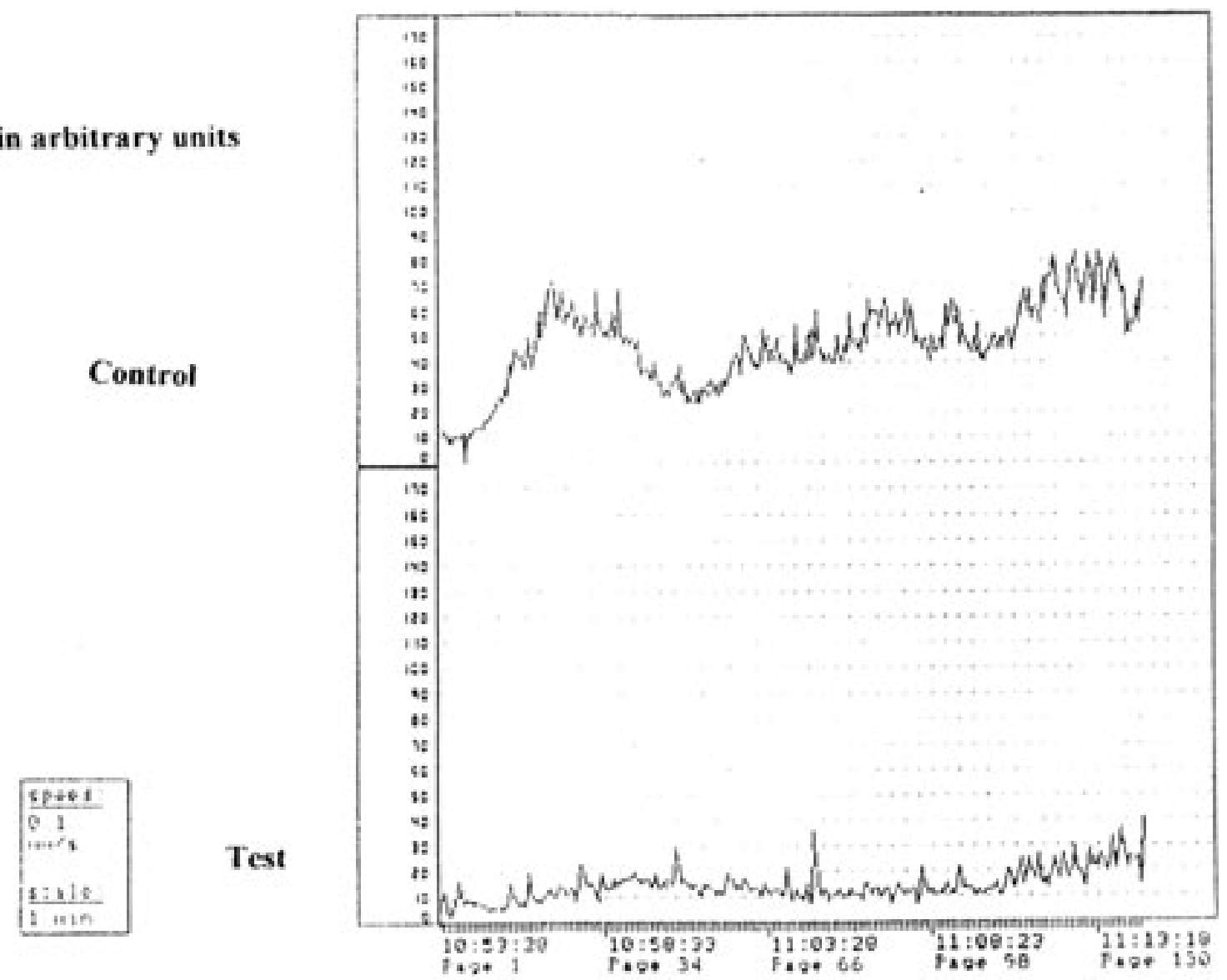

Figure 3) Graphical representation of the results of the Laser Doppler measurements for group II

TABLE 1

Statistical $t$ test analysis of immunohistochemical stains for protein gene product 9.5 (PGP 9.5), calcitonin generelated peptide (CGRP) and substance $P$ (SubP)

\begin{tabular}{lccccc}
\hline \multirow{2}{*}{ Test } & \multicolumn{2}{c}{ Percentage of red in frame } & & \multicolumn{2}{c}{ Intensity of red in frame } \\
\cline { 2 - 3 } \cline { 5 - 6 } Mean & $\mathbf{P}$ & & & Mean & $\mathbf{P}$ \\
\hline PGP 9.5 & $0.71 / 0.037$ & 0.025 & & $56.5 / 45.3$ & 0.1 \\
CGRP & $0.13 / 0.02$ & 0.001 & & $44.9 / 11.6$ & 0.001 \\
SubP & $0.23 / 0.04$ & 0.001 & & $46.8 / 27.5$ & 0.003 \\
\hline
\end{tabular}

Mean: Group I/group II

CD31 is strongly expressed in all endothelial cells including capillaries and larger vessels (3). CD31 monoclonal antibody, in addition to vWF polyclonal antibody, were used to identify the tissues of endothelial origin from the biopsies of both the normal skin and skin grafts.

In the present work, the results of the immunohistochemical stains demonstrated that although nerve tissues were generally absent, vessels were present in the split-skin grafts with no significant difference in size or quantity from the control samples.
In the present study, Laser Doppler flowmetry was used to assess blood flow both in the normal skin and in skin grafts. Laser Doppler flowmetry has previously been found to be a consistent method of measuring blood flow in both normal skin and in skin grafts (9), although the optical properties of the stratum corneum could change at higher temperatures (in the heating and reheating stages of the experiments).

The Laser Doppler flowmetry studies showed that the changes in blood flow within the skin grafts in response to the changes in temperature, although present, were slower compared with that of the normal skin at all stages during the tests, ie, there was a slower response of the blood flow to the thermal challenges. This is of interest because the vWf and CD31 immunohistochemical stains showed that vessels were present in the split-skin grafts. This, combined with finding a lack of nerve fibres within the skin grafts, may have resulted in a deficiency of the neurally mediated reflexes which control blood flow. However, the actual presence of a response of the blood flow to the changes in temperature of the skin may have been mediated by local and/or humoral factors instead of being neurally mediated (10).

Studies $(11,12)$ have implicated the nature of the wound bed in having an influence on sensory reinnervation. However, in the present study, we found no difference in either the 


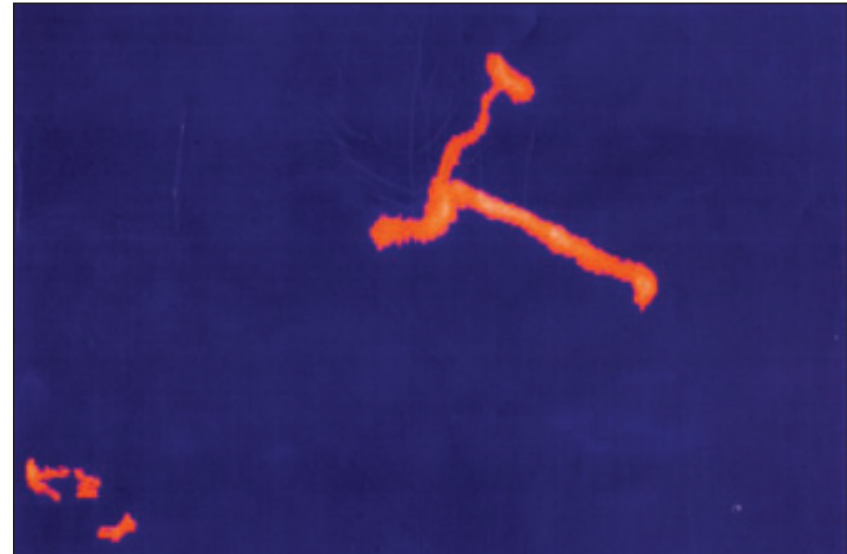

Figure 4) Red in frame of Seescan image for von Willebrand factor

TABLE 2

Statistical $t$ test analysis of immunohistochemical stains for von Willebrand factor (vWF) and CD31

\begin{tabular}{|c|c|c|c|c|c|c|}
\hline \multirow[b]{2}{*}{ Test } & \multicolumn{2}{|c|}{$\begin{array}{l}\text { Percentage of } \\
\text { red in frame }\end{array}$} & \multicolumn{2}{|c|}{$\begin{array}{l}\text { Intensity of } \\
\text { red in frame }\end{array}$} & \multicolumn{2}{|c|}{ Feret diameter } \\
\hline & Mean & $\mathbf{P}$ & Mean & $\mathbf{P}$ & Mean & $P$ \\
\hline$\overline{v W F}$ & $3.47 / 3.84$ & 0.39 & $112 / 113$ & 0.9 & $11.3 / 11.5$ & 0.92 \\
\hline CD31 & $0.59 / 0.98$ & 0.21 & $45 / 43$ & 0.25 & $5.1 / 5.2$ & 0.74 \\
\hline
\end{tabular}

Mean: Group I/group II

regeneration of nerve fibres or the pattern of blood flow in the microcirculation between the split-skin grafts on dermal or fascial beds. Both group I and group II responded somewhat similarly. Therefore, we suggest that the patterns of neural reinnervation and blood flow in split-skin grafts were independent of whether the wound bed was dermal or fascial.

\section{REFERENCES}

1. Cormack GC, Lamberty BGH. The Arterial Anatomy of Skin Flaps, 2nd edn. Edinburgh: Churchill Livingston, 1995:32-46.

2. Terenghi G. Peripheral nerve injury and reinnervation. Histol Histopathol 1995;10:709-18.

3. Kato H, Ogino T, Minami A, Usui M. Restoration of sensibility in fingers repaired with free sensory flaps from the toe. J Hand Surg [Am] 1989;14:49-54.

4. Lunberg J, Norgren L, Ribbe E, et al. Direct evidence of active sympathetic vasodilatation in the skin of the human foot. J Physiol 1989;417:437-46.

5. Walsh DA, Wharton J, Blake DR, Polak JM. Species and tissue specificity of vasoactive regulatory peptides. Int J Tissue React 1993;15:109-24.

6. Hartschuh W, Reinecke M, Weihe E, Yanaihara N. VIP-immunoreactivity in the skin of various mammals: Immunohistochemical, radioimmunological and experimental evidence for a dual localization in cutaneous nerves and merkel cells. Peptides 1984;5:239-45.

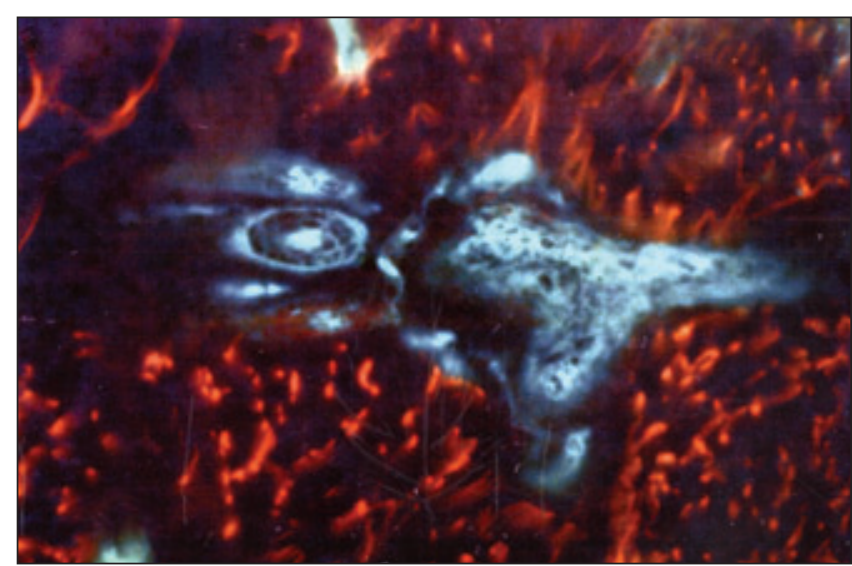

Figure 5) von Willebrand factor showing blood vessel in the subepidermal layer

\section{CONCLUSIONS}

We have found that split-skin grafts placed on both dermal and fascial beds had a lack of regenerated nerve tissues up to 15 years following the original procedure, although the presence of blood vessels was found to be similar in size and quantity to that of normal skin. We have also noted that the blood flow in the split-skin graft in response to a thermal challenge lagged behind that of 'normal' skin. We believe that this was related to the lack of regeneration of the nerve fibres of the skin grafts. Hence, we postulate that neural regeneration in split-skin grafts has less influence than local factors on the control of the microcirculation.

ACKNOWLEDGEMENTS: This paper was based on work carried out by the corresponding author at the Duke of Kent Research Centre Stoke Mandeville Hospital NHS Trust under the guidance of DA McGrouther and Anthony Roberts, without which this would not have been possible. We are also deeply indebted to the patients who participated and the nursing staff who assisted in the work.

7. Kinnman E, Weizenfield-Hallin Z. Time course and characteristics of the capacity of sensory nerves to reinnervate skin territories outside their normal innervation zone. Somatosens Mot Res 1993; 10:445-54

8. Newman PJ, Berndt MC, Gorski G, et al. PECAM-1 (CD31) cloning and relation to adhesion molecules of the immunoglobulin gene superfamily. Science 1990;247:1219-22.

9. Sunberg S. Acute effects and long-term variations in skin blood flow measured with laser Doppler flowmetry. Scand J Clin Lab Invest 1984;44:341-5.

10. Converse JM, Uhlschmid GK, Ballantyne DL Jr. "Plasmatic circulation" in skin grafts. The phase of serum imbibition. Plast Reconstr Surg 1969;43:495-9.

11. Hattori Y, Chuang DC, Lan CT. Sensory restoration of the skin graft on a free muscle flap: Experimental rabbit study. Plast Reconstr Surg 2001;108:132-40.

12. Bayramicli M, Jackson IT, Herschman B. Innervation of skin grafts over free muscle flaps. Br J Plast Surg 2000;53:130-6. 